\title{
A Study on Migration of Agriculture Labourers from Hyderabad Karnataka Area to Maharashtra
}

\author{
Dr. K. N. Doddamani \\ Associate Professor of Sociology, college of Agriculture, Gulbarga
}

\begin{abstract}
For many poor people around the world migration is a way of life, and has been for centuries. But globalization has radically altered the scale of migration: people are now more aware of opportunities elsewhere and it has become easier for them to travel. The seasonal migration of agricultural labourers is not a new phenomenon in Karnataka and India. Britishers have mobilized labour force for commercial crop production, mining and other administrative purposes during their rule. After Independence, Government of India (GOI) adopted the socialist-capitalist (mixed economy) model of development through five year planning. As a result of the defective policies of agricultural development the regional disparity is increasing, which is leading to the increase in the seasonal migration of agricultural labourers. Inclusive growth policy is an attempt to bring the backward sectors, classes, castes, tribes, women, and marginal people into main stream economy. In Karnataka state regional disparity has become a political issue. Southern Karnataka region, which is politically dominant, is developed in terms of irrigational facilities and loan availability and other basic infrastructure whereas Northern Karnataka Specially Hyderabad Karnataka regions are comparatively less developed. As a result, every year thousands of marginal farmers and landless agricultural labourers migrate seasonally to Maharashtra for survival and inclusion.
\end{abstract}

Index Terms: agriculture labour. Hyderabad Karnataka Area, regional and state migration Maharashtra.

\section{Introduction}

The term migration was usually understood to cover all cases where the decision to migrate was taken freely by the individual concerned for reasons of "personal convenience" and without intervention of an external compelling factor. It therefore applied to persons, and family members, moving to another country or region to improve their material or social conditions and to improve the prospect for themselves or their family. The United Nations defines migrant as , an individual who has resided in a foreign country for more than one year irrespective of the causes, voluntary or involuntary, and the means, regular or irregular, used to migrate. Under such a definition, those travelling for shorter periods as tourists and business persons would not be considered as migrants. However, common usage includes certain kinds of shorter-term migrants, such as seasonal farmworkers who travel for short periods to work in planting or harvesting farm products." Migration refers to the movement of people from one geographical location to another, either on a temporary or permanent basis (Ekong 2003). It is a common observation all over the world that rural-urban migration is a dominant pattern of internal migration. Migration is a selective process affecting individuals or families with certain economic, social, educational and demographic characteristics. People migrate in response to prevailing conditions and the reasons for it differ from one individual to another There are two main types of migration: first, internal migration, i.e. migration within one country, and secondly international migration, which means the movement from one country to another. Agriculture labour migration is also one type of labour migration from one place to another place for their livelihood. Agricultural labourers, especially in smaller villages away from towns and cities, are generally unskilled workers carrying on agricultural operation in the centuries old traditional ways. Most agricultural workers belong to the depressed classes, which have been neglected for ages. The low caste and depressed classes have been socially handicapped and they never had the courage to assert themselves. In some parts of India, agricultural labourers are migratory, moving in search of jobs at the time of harvesting.This movement has some time helped them to get the benefits of growth and development.

\section{Review Of Literature}

Following are some of the literature reviewed to identify the research gap.based on this the objectives of the work has been framed Manon Domingues, Dos Santo Thiser analyses the dynamics of migratory flows and growth in a developing economy. We show that when workers freely choose their location, some natives can rationally decide to return to their home country after they have accumulated a certain amount of knowledge abroad, while some prefer to stay permanently in the same economy (either at home or abroad). We point out that worker mobility can have an expansionary effect on the developing economy. Moreover, we show that in 
the long-run, as the sending economy develops, fewer natives are likely to emigrate and more migrants are likely to return.

Shigemi Yabuuchia, Sarbajit Chaudhurib(2005) develops a three sector general equilibrium structure with diverse trade pattern and imperfection in the unskilled labour market to analyze the consequences of international mobility of skilled and unskilled labour on the skilled-unskilled wage inequality in the developing economies. The analysis finds that an emigration (immigration) of either type of labour is likely to produce a favorable effect on the wage inequality. In particular, the result of emigration (immigration) of skilled labour on the relative wage inequality is counterintuitive. These results have important policy implications for an overpopulated developing country like India

Manolo I. Abella (2005) while the growth of trade may have substituted for potential movements of labour, its overall impact has been to stimulate economic growth and employment, and social and demographic changes which in turn create shortages of labour. As the regional economy continues to expand at a rapid pace, pressures will increase for importing foreign labour to do jobs that national workers no longer want.

The World Bank's (2006) Global Economic Prospects Report asserts that "migration should not be viewed as a substitute for economic development in the country of origin [as ultimately] development depends on sound domestic economic policies."

Naresh Kumar and A.S. Sidhu (2005) attempt to identify the push and pull factors which influence workers' inter-state migration, on the basis of perceptions of workers. A sample of 200 workers drawn from 25 brickkilns located in three districts of Punjab were interviewed. This study found that industrial development, better job opportunities and comparatively higher wages in Punjab have emerged as the most important pull factors which motivate labour to migrate. But lack of development, inadequate agricultural land and poor economic conditions of family forced laborers to migrate out of its native place. The study further found that economic factors have emerged more significant as compared to non-economic factors in the process of migration. Study recommends that in view of the slow absorption rate in the urban industrial sector, the labour migration should be regulated. Concrete plans and their effective implementation are necessary in order to reach the people.

\section{Research gap:}

Migration is one of the common trends in these days. In the same way agriculture labour migration is also common in these days. Agriculture labourer face so many problems in his living condition and these problems push him from his native place and migrate to other places where he get good employment and income opportunity. In Karnataka there is lot of disparities between Hyderabad Karnataka and South Karnataka and the drought is more prevalent in Hyderabad Karnataka which has led to the migration of agricultural labourers from Hyderabad Karnataka to Maharashtra in search of jobs. This study focuses on this type of migrant labourers who have migrated from Hyderabad Karnataka to Maharashtra for employment in construction fields, and tries to prove that this type of migration of the marginalized section has helped in their inclusive growth.

\section{Objectives:}

The main objectives of this paper are

1) To study the socioeconomic conditions of the migrant labourers, before and after the migration.

2) To identify whether migration has led to inclusive growth taking into consideration the income and education level as well as caste background of these people.

\section{Methodology:}

Details regarding the socio-economic conditions of the selected laborers are based on the information collected through interview schedule.100 respondents are selected from different construction fields in Maharashtra. Primary data collected from the respondents with the help of questionnaire. SPSS package is use for data analysis.The analysis of the socio-economic background of the selected seasonal migrant laborers has helped to explain the situational factors at the place of origin which make them to migrate. The specific focus of the paper is to understand the socio-economic background of migrant labourers and it is well pronounced by this study that the social and economic exclusion in the native is the main reason for agricultural labour migration.

Table .1.Age of the labourers

\begin{tabular}{|l|l|l|l|}
\hline Sl.NO & Age & Frequency & Percent \\
\hline 1 & $11-20$ & 13 & 13.00 \\
\hline 2 & $21-30$ & 32 & 32.00 \\
\hline 3 & $31-40$ & 35 & 35.00 \\
\hline 4 & $41-50$ & 20 & 20.00 \\
\hline & Total & 100 & 100.00 \\
\hline
\end{tabular}


Above table 1 has classified these labourers on the basis of age. As shown in the table it is middle age group which is showing more inclination towards migration to improve their economic status.32\% of labourers are 21-30 age group, 35\% of labourers are 31-40 age group and other remaining part fall in low and higher age group. It is clear from the table that the migration is very pronounced in the highly productive age group ie 20 40 years

Table.2. Male and Female Ratio.

\begin{tabular}{|l|l|l|l|}
\hline Sl.No & Gender & Frequency & Percentage \\
\hline 1 & Male & 32 & 32.0 \\
\hline 3 & Female & 68 & 68.0 \\
\hline & Total & 100 & 100.0 \\
\hline
\end{tabular}

The above table 2 data has been classified on the basis of gender also. And it is men who are more migratory in this group. And the $32 \%$ of female population is normally the dependent wife who follows husband to his working place. In most of the cases they are also joining the hands of their husbands to improve the family income and they expressed their willingness to work in an alien place than in their native.

Table .3 Cateogary wise Migrant Labourers

\begin{tabular}{|l|l|l|l|}
\hline Sl.No & Category & Frequency & Percentage \\
\hline 1 & 2A & 24 & 24.0 \\
\hline 2 & 2B & 10 & 10.0 \\
\hline 3 & 3A & 1 & 1.0 \\
\hline 4 & 3B & 1 & 1.0 \\
\hline 5 & Cat I & 11 & 11.0 \\
\hline 6 & SC & 28 & 28.0 \\
\hline 7 & ST & 12 & 12.0 \\
\hline & Total & 100 & 100.0 \\
\hline
\end{tabular}

The above table 3 deals with the result shows the socio - economic conditions of the migrant labourers, table 3 refers the category wise migrated laborers and their percentage. According to this table the migrated laborers from Hydrabad Karnataka has been classified into SC and STs, OBCs and others and it is very clear that out of the total more than $40 \%$ are SCs and STs ,34 \% belong to 2A. This clearly shows that the majority of the poor agricultural labourers, who migrate for their livelihood, are from this marginalized group.

Table .4 Educational levels of migrant labourers

\begin{tabular}{|l|l|l|l|}
\hline Sl.No & Education level & Frequency & Percentage \\
\hline 1 & Illiterate & 62 & 62.0 \\
\hline 2 & Primary/ Middle School & 25 & 25.0 \\
\hline 3 & High School & 8 & 8.0 \\
\hline 4 & College & 3 & 3.0 \\
\hline & & 100 & 100.0 \\
\hline
\end{tabular}

The above table reveals the education is very crucial for inclusive growth and this has been tested in this research paper and as expected the number of illiterates is very high (62\%).25\%of the labourers are having primary/ Middle school level and the maximum level of education among these people is high school level( $8 \%)$. The few people (3\%) this works like a vicious circle for these people. Tey are poor and are not able to get good education and they are not getting good education because they are poor.

Table 5 working status of migrants Status

\begin{tabular}{|l|l|l|l|}
\hline Sl.No & Status & Frequency & Percentage \\
\hline 1 & Helper & 5 & 5.0 \\
\hline 2 & Labour & 86 & 86.0 \\
\hline 3 & Mason & 9 & 9.0 \\
\hline & Total & 100 & 100.0 \\
\hline
\end{tabular}

Above table shows that the $5 \%$ people working as helper and $86 \%$ of migrants are working as labourers, The $9 \%$ people working as Mason. They are unskilled hence they draw lower wages compare to mason and other workers who are working in construction fields. 


\section{Findings}

The wage earning status of the migrant labourers before and after. There is a significant difference between income level of the migrated labourers before and after their migration. The income has actually increased. This type of migration not only helped to improve the standard of living of the migrant labourers, but also made them economically and socially included as majority of them belongs to the marginalized communities.

It is middle age group which is showing more inclination towards migration to improve their economic status.32\% of labourers are 21-30 age group, 35\% of labourers are 31-40 age group and other remaining part fall in low and higher age group. It is clear from the table that the migration is very pronounced in the highly productive age group ie 20-40 years and it is men who are more migratory in this group. And the $32 \%$ of female population is normally the dependent wife who follows husband to his working place. In most of the cases they are also joining the hands of their husbands to improve the family income and they expressed their willingness to work in an alien place than in their native.

The category wise migrated laborers and their percentage. According to this table the migrated laborers from Hyderabad Karnataka has been classified into SC and STs, OBCs and others and it is very clear that out of the total more than $40 \%$ are SCs and STs ,34 \% belong to 2A. This clearly shows that the majority of the poor agricultural labourers, who migrate for their livelihood, are from this marginalized group.

The education is very crucial for inclusive growth and this has been tested in this research paper and as expected the number of illiterates is very high $(62 \%) .25 \%$ of the labourers are having higher primary school level and the maximum level of education among these people is high school level(13\%).This works like a vicious circle for these people. They are poor and are not able to get good education and they are not getting good education because they are poor. The $86 \%$ of migrants are working as labourers, they are unskilled hence they draw lower wages compare to mason and other workers who are working in construction fields.

\section{Conclusion}

The above study helps us to make some observation as below. The migrant labourers from Hyderabad Karnataka are becoming the main labour source to the construction sector in the cities and the construction works of the cities are pulling these labourers because of high wages. Migrated labourers are coming to Maharashtra region in good number for employment to fulfilling their financial as well as social needs. Most of the labourers are landless labourer and agricultural labourers only few have own land holding but they find it very difficult to survive because of this adverse environment in agriculture sector, Therefore they migrate. Since majority of these migrant labourers have come from poor background and low socio economic status, the migration has helped them to improve not only their financial status but also their educational, social status. In this way they felt that the migration has helped them to get included in the development process.

[1]. Global Economic Prospects (2006) the World Bank

[2]. J,Edward Taylor, Joaquin Arango,(1996), International Migration and Community Development, Population Index, Vol. 62, No. 3, pp. 397-418.

[3]. Jajati Keshari Parida,S Madheswaran,(2011) "Determinants Of Migration And Remittance In India, Empirical Evidence" The Institute for Social and Economic Change, Bangalore, Working paper272.

[4]. Kalpana Bardhan(1973)Factors Affecting Wage Rates for Agricultural Labour” Economic and Political Weekly, Vol. 8, No. 26, pp. A56-A64

[5]. M. S. A. Rao (1966) "Urbanisation in a Delhi Village: Some Social Aspects" Economic and Political Weekly, Vol. 1, No. 9 , pp. 365-370.

[6]. M. S. Gore (1975)'Development and a Strategy for Urbanisation: Absence of a Positive 115+117-119.

[7]. M.H. Wani, Shahid Yousuf, S.H. Baba and S.A. Wani(2011), "agricultural labour migration: causes and implications", Agricultural Economics Research Review Vol. 24 (Conference Number) 2011

[8]. Nata Duvvury,(1989")Women in Agriculture: A Review of the Indian Literature” Economic and Political Weekly, Vol. 24, No. 43 (Oct. 28, 1989), pp. WS96-WS112

[9]. Nigel Harris (2005)"Migration and Development" Economic and Political Weekly, Vol. 40, No. 43, pp. 4591-4595.

[10]. Nirmala Banerjee (1969)"What Course for Urbanisation in India?" Economic and Political Weekly, Vol. 4, No. 28/30, pp. 11731176.

[11]. Omprakash Parganiha1, M.L. Sharma2, P.M. Paraye,(2009)Migration Effect of Agricultural Labourers on Agricultural Activities, Indian Res. J. Ext. Edu. 9 (3), September, 2009

[12]. P. Parthasarathy Rao, P. S. Birthal and P. K. Joshi (2006)"Diversification towards High Value Agriculture: Role of Urbanization and Infrastructure", Economic and Political Weekly, Vol. 41, No. 26, pp. 2747-2753

[13]. Pabitra Giri (1998)Urbanisation in West Bengal, 1951-1991, Economic and Political Weekly, Vol. 33, No. 47/48, pp. 30333035+3037-3038.

[14]. Per Lundborg and Paul S. Segerstrom (2000), International Migration and Growth in Developed Countries: A Theoretical Analysis, Economica, New Series, Vol. 67, No. 268 (Nov., 2000), pp. 579-604.

[15]. Robyn Eversole (2008) "Development in Motion: What to Think about Migration? “, Development in Practice”, Vol. 18, No. 1, pp. 94-99.

[16]. Roel Jennissen: (2007),"Causality Chains in the International Migration Systems Approach”, Population Research and Policy Review, Vol. 26, No. 4 pp. 411-436. [17] 